\title{
Influence of aging and chronic heart failure on temporal dispersion of myocardial repolarization
}

This article was published in the following Dove Press journal:

Clinical Interventions in Aging

9 March 2013

Number of times this article has been viewed

\author{
Gianfranco Piccirillo' \\ Federica Moscucci' \\ Matteo Pascucci' \\ Maria Antonella Pappadà' \\ Gaetana D'Alessandro' \\ Pietro Rossi \\ Raffaele Quaglione' \\ Daniele Di Barba' \\ Francesco Barillà \\ Damiano Magri ${ }^{3}$ \\ 'Department of Cardiovascular, \\ Respiratory, Nephrological and \\ Geriatric Sciences, Policlinico \\ Umberto I, "Sapienza" University \\ of Rome, Rome, Italy; ${ }^{2}$ Division of \\ Cardiology, S. Giovanni Calabita \\ Fatebenefratelli Hospital, Rome, \\ Italy; ${ }^{3}$ Department of Clinical and \\ Molecular Medicine, Sant'Andrea \\ Hospital, "Sapienza" University of \\ Rome, Rome, Italy
}

Background and purpose: QT and $\mathrm{T}_{\text {peak }}-\mathrm{T}_{\text {end }}(\mathrm{Te})$ intervals are associated with sudden cardiac death in patients with chronic heart failure $(\mathrm{CHF})$. We studied age-dependent influence on shortterm temporal dispersion of these two variables in patients with postischemic CHF.

Method: We grouped $75 \mathrm{CHF}$ and 53 healthy control subjects into three age subsets: $\leq 50$ years, $>50$ years and $\leq 65$ years, and $>65$ years. We then calculated the following indices: QT and Te variability index (QTVI and TeVI), the ratio between the short-term variability (STV) of QT or Te, and the STV of resting rate (RR) (QT/RR STV and Te/RR STV).

Results: In all different age subgroups, patients with CHF showed a higher level of QTVI than age-matched control subjects ( $\leq 50$ years: $P<0.0001$; $>50$ years and $\leq 65$ years: $P<0.05$; $>65$ years: $P<0.05$ ). Patients with $\mathrm{CHF}<50$ years old also had all repolarization variability indices higher than normal age-matched controls (TeVI, $P<0.05$; QT/RR STV, $P<0.05$; Te/RR STV, $P<0.05$ ), whereas we did not find any difference between the two older classes of subjects. Both QTVI $\left(r^{2}: 0.178, P<0.05\right)$ and TeVI $\left(r^{2}: 0.433, P<0.001\right)$ were positively related to age in normal subjects, even if the first correlation was weaker than the second one. Conclusion: Our data showed that QTVI could be used in all ages to evaluate repolarization temporal liability, whereas the other indices are deeply influenced by age. Probably, the agedependent increase in QTVI was more influenced by a reduction of RR variability reported in older normal subjects.

Keywords: aging, QT variability, heart rate variability, chronic heart failure, sudden death

\section{Introduction}

Malignant ventricular arrhythmias are common complications of chronic heart failure (CHF) induced by myocardial infarction. Senescence ${ }^{1,2}$ and $\mathrm{CHF}^{3,4}$ strongly influence the cardiovascular autonomic control and myocardial repolarization phase..$^{5-9}$ Indeed, both these conditions are able to increase $\alpha$-adrenoreceptor-mediated peripheral resistance ${ }^{1}$ and to reduce $\beta$-adrenergic adrenoreceptor ${ }^{10}$ and baroreflex function, ${ }^{10,11}$ with a consistent decrease of heart rate variability. ${ }^{12-16}$ The increase of temporal dispersion of the repolarization ventricular phase $\mathrm{e}^{17-25}$ and the reduction of heart rate variability ${ }^{25-27}$ are risk factors for ventricular malignant arrhythmias and sudden cardiac death (SCD) and non-SCD. Aging ${ }^{28-30}$ and $\mathrm{CHF}^{31}$ are clear pathogenetic factors able to induce ventricular arrhythmogenesis. Neurohumoral activation, ${ }^{4,6,32}$ electroanatomical remodeling, ${ }^{33,34}$ chronic inflammatory condition, ${ }^{35}$ and endothelial dysfunction $^{36-39}$ are well-recognized causes of ventricular arrhythmia in patients with CHF. Elderly patients with CHF show higher proneness for the malignant ventricular arrhythmias because these subjects have lower levels of functional reserve capable of
Correspondence: Gianfranco Piccirillo Dipartimento di Scienze Cardiovascolari, Respiratorie, Nefrologiche, Anestesiologiche e Geriatriche Università "La Sapienza", Viale del Policlinico, 00185 - Rome, Italy Tel +3906 499701 I 8

Email gianfranco.piccirillo@uniromal.it 
resisting arrhythmogenesis. Although the influence of $\mathrm{CHF}$ and aging on ventricular arrhythmias is well known, the underlying pathogenic mechanisms are not yet completely understood. Particularly, the impact of aging on markers of repolarization's temporal dispersion during CHF has not been clarified. In a recent large community-based study, an increased risk of SCD has been found related to a prolonged $\mathrm{T}_{\text {peak }}-\mathrm{T}_{\text {end }}$ interval (Te). ${ }^{40}$ In addition, in patients with $\mathrm{CHF}$ and $\mathrm{SCD}$, a higher temporal dispersion was reported. ${ }^{5}$

All in all, we analyzed QT interval (from Q to end T wave electrocardiogram [ECG]) variability index (QTVI) and short-term variability (STV) of QT in CHF subjects with different ages, in order to individuate a possible age-dependent influence on these markers. Finally, we calculated the same indices of variability on the last part of the $T$ wave (considering the peak and end of the $\mathrm{T}$ wave) to observe a peculiar age-related effect on this important part of repolarization.

\section{Methods}

\section{Study subjects}

For this study we selected 75 outpatients (63 men and 12 woman) who had stable CHF secondary to ischemic dilated cardiomyopathy, and 53 healthy control subjects (41 men and 12 women). We defined clinically stable patients as those who had not been hospitalized or had their therapy adjusted or had experienced any other acute coronary artery or noncoronary event during the past 3 months. All participants had undergone revascularization either cutaneously or by aortocoronary artery bypass at least 3 months before the study. None of the patients had malignancy, primary valve disease, atrial fibrillation, premature complexes (one premature complex per minute was permitted), or other arrhythmias likely to interfere with heart rate and QT analysis. None of the patients was New York Heart Association class IV. Before the study, none of the subjects had a documented history of cardiac arrest, ventricular tachycardia, or fibrillation. We suggested that all patients with ejection fraction $\leq 35 \%$ underwent an implant of implantable cardioverter/defibrillator device.

To detect possible statistical differences related to age we divided each of the two study groups into three age subsets: $\leq 50$ years, $>50$ years and $\leq 65$ years, and $>65$ years.

\section{Study protocol and offline data analysis}

After a 10-minute rest lying down, each subject underwent a 5-minute, single ECG lead recording during controlled breathing (15 breaths per minute, $0.25 \mathrm{~Hz}$ ). All digitized signal recordings were analyzed by a single physician (GP) blinded to the subjects' circumstances.
We measured the following intervals from the respective time series of ECG recordings: resting rate (RR), QT (from the $\mathrm{Q}$ wave to the $\mathrm{T}$ wave end), and Te (from the $\mathrm{T}$ peak to $\mathrm{T}$ wave end). We therefore calculated mean and variance values of each of these intervals and then used the original formula proposed by Berger et $\mathrm{al}^{41}$ to calculate three different QT variability indices:

$$
\begin{gathered}
\text { QTVI }=\log _{10}\left\{\left[\left[\mathrm{QT}_{\text {variance }}\right] /\left[\mathrm{QT}_{\text {mean }}\right]^{2}\right] /\left[\left[\mathrm{RR}_{\text {variance }}\right] /\left[\mathrm{RR}_{\text {mean }}\right]^{2}\right]\right\} \\
\mathrm{TeVI}=\log _{10}\left\{\left[\left[\mathrm{~T}_{\text {Evariance }}\right] /\left[\mathrm{T}_{\text {Emean }}\right]^{2}\right] /\left[\left[\mathrm{RR}_{\text {variance }}\right] /\left[\mathrm{RR}_{\text {mean }}\right]^{2}\right]\right\}
\end{gathered}
$$

Software for data acquisition and storage and for spectral analysis were designed and produced by our research group and are described in detail elsewhere. ${ }^{7-9,42-45}$

Finally, we used all ECG recordings to measure the STV of the aforementioned intervals. This variable was calculated following the standard method, namely by using the first 60 consecutive beats $\left(\mathrm{STV}_{60}\right)^{6,46,47}$ and also by using the total number of beats in the whole 5-minute recording $\left(\mathrm{STV}_{\mathrm{T}}\right)$. The formula used was:

$$
\begin{gathered}
\operatorname{STV}_{60}=\Sigma\left[D_{n+1}-D_{n}\right](60 \times \sqrt{ } 2) \\
\operatorname{STV}_{T}=\Sigma\left[D_{n+1}-D_{n}\right](\text { total beats number } \times \sqrt{ } 2)
\end{gathered}
$$

where D was the duration of RR or QTe, or Te interval. Consequently, we were able to obtain the following six STV indices: RR STV 60 , QT STV 60 , Te STV 60 , RR STV $\mathrm{STV}_{\mathrm{T}}$, and Te $\mathrm{STV}_{\mathrm{T}}$.

Finally, we calculated the following ratio between the different STVs:

$$
\begin{aligned}
& \mathrm{QT} / \mathrm{RR} \mathrm{STV}_{60}=\mathrm{QT} \mathrm{STV}{ }_{60} / \mathrm{RR} \mathrm{STV}_{60} \text {; } \\
& \mathrm{Te} / \mathrm{RR} \mathrm{STV}_{60}=\mathrm{Te} \mathrm{STV}_{60} / \mathrm{RR} \mathrm{STV}_{60} \\
& \text { QT/RR STV } \mathrm{T}_{\mathrm{T}}=\mathrm{QT} \mathrm{STV}_{\mathrm{T}} / \mathrm{RR} \mathrm{STV}_{\mathrm{T}} \text {; } \\
& \mathrm{Te} / \mathrm{RR} \mathrm{STV}_{\mathrm{T}}=\mathrm{Te} \mathrm{STV}_{\mathrm{T}} / \mathrm{RR} \mathrm{STV}_{\mathrm{T}}
\end{aligned}
$$

Moreover, from the same 5-minute ECG segment, the corrected QT and Te intervals were obtained according to the formulas proposed by Bazett $\left(\mathrm{QT} / \mathrm{RR}^{0.5}\right.$; QT; $\left.\mathrm{Te} / \mathrm{RR}^{0.5}\right)$, Friedericia $\left(\mathrm{QT} / \mathrm{RR}^{0.33} ; \mathrm{Te} / \mathrm{RR}^{0.33}\right), \mathrm{Lilly}\left(\mathrm{QT} / \mathrm{RR}^{0.4}\right.$; $\left.\mathrm{T}_{\mathrm{e}} / \mathrm{RR}^{0.4}\right)$, and Framingham $\left(\mathrm{QT}_{+}[0.154 *\{1000-\mathrm{RR}\}]\right.$; Te+ $[0.154 *\{1000-\mathrm{RR}\}])$.

\section{Statistical analysis}

Unless otherwise indicated, all data are expressed as means \pm standard deviation. Data with skewed distribution are given as median and interquartile range (75th percentile-25th percentile). 
Categorical variables were analyzed with the $\chi^{2}$ test. Oneway analysis of variance and the Bonferroni test were used to compare data for the normally distributed variables. Kruskal-Wallis and Mann-Whitney tests were used to compare non-normally distributed variables (as evaluated by the Kolmogorov-Smirnov test). To detect possible statistical differences related to age, we divided each of the two study groups into three age subsets: $\leq 50$ years, $>50$ years and $\leq 65$ years, and $\geq 65$ years.

Stepwise multiple regression analysis was used to determine possible relationships between the studied variables. $P$-values $\leq 0.05$ were considered statistically significant. All data were evaluated with the database SPSS-PC+ (SPSS-PC+ Inc, Chicago, IL, USA).

\section{Results}

We examined 128 subjects, 75 with CHF and 53 healthy controls. The clinical characteristics of subjects enrolled in the study are shown in Table 1.

Age, body mass index, and sex distribution did not differ significantly between the two groups, whereas heart rate, diastolic arterial pressure, left ventricular ejection fraction, and

Table I General characteristics of study sample

\begin{tabular}{|c|c|c|c|}
\hline Characteristics & $\begin{array}{l}\text { Chronic } \\
\text { heart failure } \\
\mathbf{N}=75\end{array}$ & $\begin{array}{l}\text { Healthy } \\
\text { controls } \\
N=53\end{array}$ & $P$ values \\
\hline Age, years & $64 \pm 13$ & $60 \pm 15$ & 0.452 \\
\hline Male/female & $63 / 12$ & $41 / 12$ & 0.275 \\
\hline BMI, $\mathrm{kg} / \mathrm{m}^{2}$ & $26 \pm 4$ & $26 \pm 3$ & 0.155 \\
\hline $\mathrm{HR}$, beats/min & $66 \pm 11$ & $68 \pm 10$ & 0.329 \\
\hline $\begin{array}{l}\text { Systolic blood pressure, } \\
\mathrm{mmHg}\end{array}$ & $123 \pm 26$ & $122 \pm 17$ & 0.700 \\
\hline $\begin{array}{l}\text { Diastolic blood pressure, } \\
\mathrm{mmHg}\end{array}$ & $66 \pm 15$ & $75 \pm 11$ & 0.002 \\
\hline $\begin{array}{l}\text { Left ventricular ejection } \\
\text { fraction, } \%\end{array}$ & $40 \pm 10$ & $57 \pm 4$ & 0.0001 \\
\hline $\mathrm{QT}, \mathrm{ms}$ & $375 \pm 58$ & $353 \pm 26$ & 0.007 \\
\hline $\mathrm{QT}_{\text {Bazett }}, \mathrm{ms}$ & $389 \pm 51$ & $372 \pm 20$ & 0.017 \\
\hline $\mathrm{QT}_{\text {Fridericia' }}, \mathrm{ms}$ & $384 \pm 51$ & $366 \pm 19$ & 0.008 \\
\hline $\mathrm{QT}_{\text {Lilly }}, \mathrm{ms}$ & $386 \pm 51$ & $361 \pm 19$ & 0.011 \\
\hline $\mathrm{QT}_{\text {Framingham }}, \mathrm{ms}$ & $385 \pm 51$ & $368 \pm 18$ & 0.012 \\
\hline NYHA class, I/II/III & $10 / 46 / 19$ & 0 & 0.0001 \\
\hline Serum $\mathrm{K}^{+} \mathrm{mmEq} / \mathrm{L}$ & 4.2 & 4.1 & 0.842 \\
\hline$\beta$-blockers & 35 & 0 & 0.0001 \\
\hline Furosemide & 33 & 0 & 0.0001 \\
\hline ACEi/Sartans & 56 & 5 & 0.0001 \\
\hline Spironolactone & 22 & 0 & 0.0001 \\
\hline Digoxin & 13 & 0 & 0.0001 \\
\hline Amiodarone & 11 & 0 & 0.017 \\
\hline
\end{tabular}

Note: Data are expressed as means \pm standard deviation.

Abbreviations: BMl, body mass index; HR, heart rate; NYHA, New York Heart Association; $\mathrm{ACEi}$, angiotensin converting enzyme; $\mathrm{ms}$, milliseconds; $\mathrm{mmEq} / \mathrm{L}$ milliequivalents per liter.
QT interval differed significantly (Table 1). Both subgroups had a similar mean intergroup age (Table 2).

The younger CHF group showed a reduction of RR variance in comparison with the age-matched healthy controls, whereas only the older CHF group reported a longer $\mathrm{RR}_{\text {mean }}$ than controls (Table 3 ). Only elderly subjects had a significantly larger $\mathrm{QT}_{\text {mean }}(P<0.05)$, QT variance $(P<0.05)$, and $\mathrm{Te}_{\text {mean }}(P<0.05)$ than age-matched healthy controls. Furthermore, the middle-aged group showed a $\mathrm{QT}_{\text {variance }}(P<0.05)$ significantly higher than age-matched controls (Table 3 ). In all subsets, independently from age, the CHF group showed a significantly higher QTVI $(P<0.001)$ than age-matched controls, but only the younger CHF group had all other QT variability values significantly higher (TeVI: $P<0.05$, QT/ $\mathrm{RR} \mathrm{STV}_{60}: P<0.05, \mathrm{Te} / \mathrm{RR} \mathrm{STV}_{60}: P<0.05, \mathrm{QT} / \mathrm{RR} \mathrm{STV}_{\mathrm{T}}$ : $P<0.05$, and Te/RR STV $: P<0.05)$ in comparison with age-matched controls (Table 4 ). In the middle-aged and elderly CHF groups we did not find any differences for the other repolarization variables (Table 4).

We did not find any difference between the three CHF groups in respect of the RR and QT variables (Tables 3 and 4). $\mathrm{RR}_{\text {variance }}(P<0.001)$ was significantly higher in younger and middle-aged control subjects than older subjects (Table 3), and this variable was also significantly higher in younger controls compared with healthy middle-aged subjects. Te $(P<0.05)$ was higher in younger and middle-aged control subjects than older subjects (Table 3 ). On the other hand, $\mathrm{Te}_{\text {variance }}(P<0.05)$ was higher in the two younger groups than the older normal subjects.

In the control group, all temporal dispersion variables (QTVI, TeVI, QT/RR STV ${ }_{60}$, Te/RR STV 60 , QT/RR STV $\mathrm{Te} / \mathrm{RR} \mathrm{STV}_{\mathrm{T}}$ ) were significantly lower in the younger group in comparison with the older subjects $(P<0.05)$ (Table 4$)$. QTVI, TeVI, QT/RR STV ${ }_{\mathrm{T}}$, and Te/RR STV $\mathrm{T}_{\mathrm{T}}$ were lower in the middle-aged subjects than in the older ones. Only QTVI results were significantly lower in the younger control group compared with the middle-aged group (Table 4).

Table 2 Mean age of subjects in the three age-subgroups

\begin{tabular}{|c|c|c|c|}
\hline Age subgroups & $\begin{array}{l}\text { Chronic } \\
\text { heart failure } \\
N=75\end{array}$ & $\begin{array}{l}\text { Healthy } \\
\text { controls } \\
N=53\end{array}$ & $P$ values \\
\hline$\leq 50$ years & $\begin{array}{l}46 \pm 4 \\
(n=19)\end{array}$ & $\begin{array}{l}44 \pm 3 \\
(n=17)\end{array}$ & $0.37 I$ \\
\hline$>50 \leq 65$ years & $\begin{array}{l}58 \pm 3 \\
(n=2 I)\end{array}$ & $\begin{array}{l}57 \pm 4 \\
(n=18)\end{array}$ & 0.342 \\
\hline$\geq 65$ years & $\begin{array}{l}75 \pm 6 \\
(n=35)\end{array}$ & $\begin{array}{l}77 \pm 4 \\
(n=18)\end{array}$ & 0.317 \\
\hline
\end{tabular}

Note: Data are expressed as means \pm standard deviation. 
Table 3 RR interval and QT dynamics data according to age and presence of chronic heart failure

\begin{tabular}{|c|c|c|c|c|c|c|c|c|c|}
\hline \multirow[t]{2}{*}{ Variables } & \multicolumn{2}{|c|}{$\begin{array}{l}\text { Group I } \\
\text { ( } \leq 50 \text { years) }\end{array}$} & \multirow[t]{2}{*}{$P$} & \multicolumn{2}{|c|}{$\begin{array}{l}\text { Group } 2 \\
(>50 \leq 65 \text { years })\end{array}$} & \multirow[t]{2}{*}{$P$} & \multicolumn{2}{|c|}{$\begin{array}{l}\text { Group } 3 \\
\text { ( } \geq 65 \text { years) }\end{array}$} & \multirow[t]{2}{*}{$P$} \\
\hline & $\begin{array}{l}\text { CHF } \\
(N=19)\end{array}$ & $\begin{array}{l}\text { Controls } \\
(N=17)\end{array}$ & & $\begin{array}{l}\text { CHF } \\
(N=2 I)\end{array}$ & $\begin{array}{l}\text { Controls } \\
(N=18)\end{array}$ & & $\begin{array}{l}\text { CHF } \\
(N=35)\end{array}$ & $\begin{array}{l}\text { Controls } \\
(N=18)\end{array}$ & \\
\hline $\mathrm{RR}$ mean, ms & $899 \pm 154$ & $945 \pm 142$ & 0.354 & $918 \pm 140$ & $906 \pm 127$ & 0.785 & $966(164)$ & $873(126)$ & 0.040 \\
\hline $\mathrm{RR}$ variance, $\mathrm{ms}^{2}$ & $574(1 \mathrm{I} 24)$ & $1627(2244)^{*}$,\# & 0.0001 & $805 \pm 1309$ & $885 \pm 990^{\S}$ & 0.349 & $611(820)$ & $580(1340)$ & 0.992 \\
\hline QT mean, ms & $363 \pm 42$ & $359 \pm 30$ & 0.801 & $371 \pm 57$ & $355 \pm 31$ & 0.294 & $385 \pm 66$ & $347 \pm 18$ & 0.008 \\
\hline $\mathrm{QT}$ variance, $\mathrm{ms}^{2}$ & $36(84)$ & $18(14)$ & 0.066 & $43(76)$ & $19(10)$ & 0.011 & $38(67)$ & $14(52)$ & 0.004 \\
\hline Te mean, ms & $85 \pm 29$ & $86 \pm 13^{\#}$ & 0.847 & $81 \pm 18$ & $87 \pm 22^{\dagger}$ & 0.402 & $91 \pm 43$ & $70 \pm 13$ & 0.019 \\
\hline Te variance, $\mathrm{ms}^{2}$ & $23(80)$ & $20(16)^{\#}$ & 0.397 & $38(85)$ & $17(33)^{\dagger}$ & 0.349 & $33(80)$ & $39(35)$ & 0.696 \\
\hline
\end{tabular}

Notes: Data are expressed as median and interquartile range (75th-25th). "P $<0.05$ Group I vs Group 2; \#P< 0.05 Group I vs Group 3; ${ }^{+} P<0.05$ Group 2 vs Group 3; $\S p<0.001$ Group 2 vs Group 3.

Abbreviations: $\mathrm{CHF}$, chronic heart failure; $\mathrm{TeVI}, \mathrm{T}_{\text {peak }}{ }^{-\mathrm{T}_{\text {end }}}$ variability index; RR mean or variance, waves interval; $\mathrm{ms}$, milliseconds; $\mathrm{QT}$ interval mean or variance.

The stepwise multiple regression analysis found a significant relation with QTVI and ejection fraction (R: $\left.0.364 ; \mathrm{R}^{2}: 0.132, \beta:-0.364, P: 0.001\right)$ in CHF subjects. Instead, QTVI $(P<0.05)$, TeVI $(P<0.001)$, QT/RR $\operatorname{STV}_{60}(P<0.05), \mathrm{Te} / \mathrm{RR} \mathrm{STV}_{60}(P<0.05), \mathrm{QT} / \mathrm{RR} \mathrm{STV}$ T $(P<0.001)$, and Te/RR $\operatorname{STV}_{\mathrm{T}}(P<0.001)$ showed a significant positive relation with aging in control groups (Figures 1 and 2). We also found a negative significant correlation between all measures of RR variability and age (Figure 3) in the same subjects. Except for $\mathrm{Te}_{\text {variance }} /\left(\mathrm{T}_{\text {mean }}{ }^{2}\right)$ (Figure 4), we did not find any significant correlation between age and repolarization variables without RR normalization in the control group.

\section{Discussion}

Our main and original finding was that only QTVI values remained significantly higher in patients with CHF regardless of their age, whereas all other indices of temporal myocardial repolarization dispersion were significantly higher only in those patients with CHF belonging to the youngest category, namely those characterized with an age $\leq 50$ years. Our second, somewhat confirmatory, finding was the significant positive correlation between QTVI and left ventricular ejection fraction in patients with $\mathrm{CHF},{ }^{10}$ whereas, in healthy control subjects, all repolarization variability parameters showed a significant relation only with age. Thus, although QTVI suffers a certain age influence, this index seems to be the only useful variable to measure temporal dispersion of myocardial repolarization independently from age of the patients with CHF.

An increase in temporal myocardial repolarization dispersion, as assessed by several QT interval-derived indices, has been proven to be significantly associated with an increased SCD risk in patients with structural heart disease. ${ }^{17-21,41-44}$ However, it is well known that, particularly in patients with CHF, aging represents an additional feature able to magnify this risk, most likely through a further increase in myocardial repolarization lability. Indeed, aging typically leads to a prolongation of action potential duration due to different mechanisms, such as an increased number and overactivity of cardiac L-type $\mathrm{Ca}^{2+}$ channels with a consequent slow inactivation of calcium influx and a reduction in outward potassium current. ${ }^{48,49}$ As a result, with aging, the QT length and variability tends to increase. Nonetheless, it should be

Table 4 QT variability indices according to age and presence of chronic heart failure

\begin{tabular}{|c|c|c|c|c|c|c|c|c|c|}
\hline \multirow[t]{2}{*}{ Variables } & \multicolumn{2}{|l|}{$\begin{array}{l}\text { Group I } \\
(\leq \mathbf{5 0} \text { years })\end{array}$} & \multirow[t]{2}{*}{$P$} & \multicolumn{2}{|c|}{$\begin{array}{l}\text { Group } 2 \\
(>50 \leq 65 \text { years })\end{array}$} & \multirow[t]{2}{*}{$P$} & \multicolumn{2}{|l|}{$\begin{array}{l}\text { Group } 3 \\
\text { ( } \geq 65 \text { years) }\end{array}$} & \multirow[t]{2}{*}{$P$} \\
\hline & $\begin{array}{l}\text { CHF } \\
(N=19)\end{array}$ & $\begin{array}{l}\text { Controls } \\
(N=17)\end{array}$ & & $\begin{array}{l}\text { CHF } \\
(N=2 I)\end{array}$ & $\begin{array}{l}\text { Controls } \\
(\mathrm{N}=18)\end{array}$ & & $\begin{array}{l}\text { CHF } \\
(N=35)\end{array}$ & $\begin{array}{l}\text { Controls } \\
(N=18)\end{array}$ & \\
\hline QTVI & $-0.40(1.00)$ & $-1.22(0.35)^{*, \#}$ & 0.0001 & $-0.54(0.88)$ & $-1.09(0.28)^{\dagger}$ & 0.001 & $-0.38(0.90)$ & $-0.77(0.62)$ & 0.033 \\
\hline TeVI & $0.96(1.00)$ & $0.20(0.66)^{*}$ & 0.003 & $0.72(1.02)$ & $0.47(0.69)^{\S}$ & 0.133 & $0.77(1.38)$ & $1.12(0.72)$ & 0.551 \\
\hline QT/RR STV 60 & $0.49(0.58)$ & $0.17(0.63)^{\#}$ & 0.002 & $0.38(0.75)$ & $0.27(0.46)$ & 0.438 & $0.53(0.70)$ & $0.37(0.5 \mathrm{I})$ & 0.393 \\
\hline Te/RR STV 60 & $0.54(\mathrm{I} .28)$ & $0.26(0.28)^{\#}$ & 0.030 & $0.31(0.65)$ & $0.33(0.52)$ & 0.982 & $0.48(0.8 \mathrm{I})$ & $0.58(0.79)$ & 0.794 \\
\hline $\mathrm{QT} / R R \mathrm{STV} \mathrm{T}_{\mathrm{T}}$ & $0.59(0.38)$ & $0.18(0.20)^{*}$ & 0.001 & $0.40(0.33)$ & $0.3 \mathrm{I}(0.2 \mathrm{I})^{\dagger}$ & 0.256 & $0.44(0.62)$ & $0.47(0.7 \mathrm{I})$ & 0.460 \\
\hline $\mathrm{Te} / \mathrm{RR}_{\mathrm{STV}} \mathrm{T}_{\mathrm{T}}$ & 0.53 (I.09) & $0.25(0.26)^{*}$ & 0.022 & $0.37(0.36)$ & $0.33(0.34)^{\dagger}$ & 0.707 & $0.46(0.76)$ & $0.81(\mathrm{I} .1 \mathrm{I})$ & 0.223 \\
\hline
\end{tabular}

Notes: Data are expressed as median and interquartile range (75th-25th). *P $<0.05$ Group I vs Group 2; ${ }^{P}<0.05$ Group I vs Group 3; ${ }^{*} P<0.00$ I Group I vs Group 3; ${ }^{\dagger} p<0.05$ Group 2 vs Group 3; ${ }^{\circledR} P<0.00$ I Group 2 vs Group 3.

Abbreviations: QTVI, QT variability index; TeVI, $\mathrm{T}_{\text {peak }}-\mathrm{T}_{\text {end }}$ variability index; STV, short term variability. 


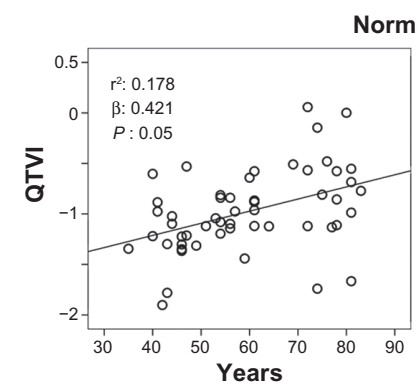

Normal subjects

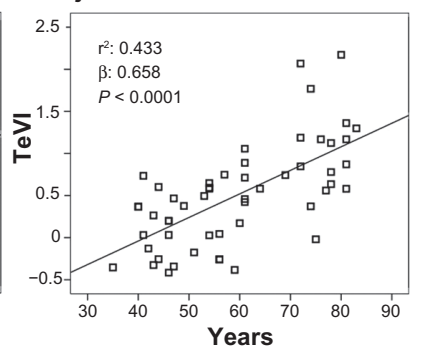

Figure I Relationship between QT variability index (QTVI) or $\mathrm{T}_{\text {peak }}{ }^{-\mathrm{T}_{\text {end }}}$ variability index $(\mathrm{TeVl})$ and age in healthy control subjects.

Abbreviation: $\mathrm{QT}$, from the $\mathrm{Q}$ wave to the $\mathrm{T}$ wave end.

emphasized that CHF leads to a prolongation and dispersion of action potential duration that is quantitatively more pronounced in respect of pure aging. Specifically, functional downregulation of potassium current and an alteration in depolarizing sodium and calcium currents are responsible for electrical remodeling, with a consequent increase in QT temporal dispersion in $\mathrm{CHF}^{50}$ Our data, besides confirming that QT variability-derived indices are significantly higher in patients with CHF compared with healthy controls, suggest that aging might represent a confounding factor for a number of them but not for QTVI. Initially, our data also suggested through which mechanisms QTVI remains a solid marker of myocardial repolarization lability despite aging. Indeed, in patients with CHF aged $\leq 50$ years, QTVI suffers because of extremely low RR variance values, whereas, considering those patients with CHF aged $>50$ years, QTVI was much worse, as indicated by a marked increase in QT variance. Thus, it could be hypothesized that in relatively young patients with CHF, an increased QTVI might mirror a sinus node dysfunction due to a prevalent autonomic nervous system control derangement, whereas, with aging, QTVI mainly reflects an altered myocardial repolarization phase. A possible reason underlying a major role of sinus node dysfunction in worsening QTVI of young patients with CHF could be represented by the well-known age-related decline in heart rate variability. ${ }^{11-16}$

Evidence indicates that an increased Te interval ${ }^{40}$ is related to $\mathrm{SCD}$, and also recent research from our group showed an increased temporal dispersion of the last part of repolarization (TeVI) in patients with $\mathrm{CHF}^{5}$ and $\mathrm{SCD}$, as well as in an animal model with pacing-induced heart failure (TeVI, Te/STV $\left.\mathrm{T}_{\mathrm{T}}\right){ }^{6}$ However, the pathophysiologic meaning of this ECG interval still remains controversial.

\section{Normal subjects}
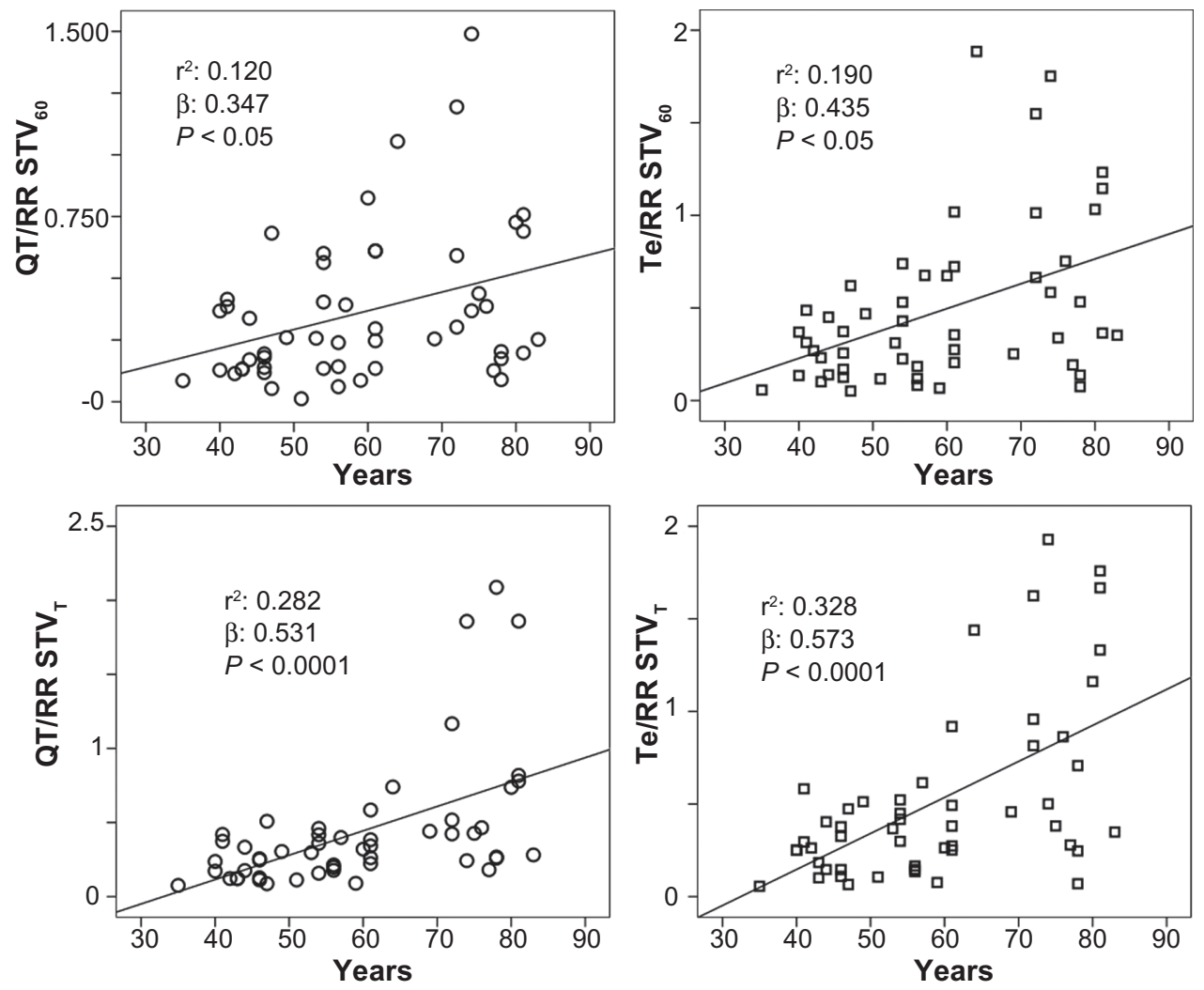

Figure 2 Relationship between age and ratio of short-term QT or $\mathrm{T}_{\text {peak }}{ }^{-\mathrm{T}_{\text {end }}}$ (Te) variability (STV) and resting rate (RR) variability indices, calculated on 60 consecutive beats

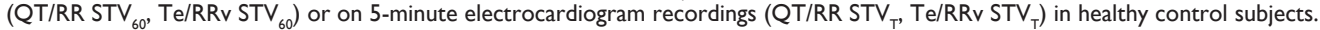

Abbreviations: $\mathrm{QT}$, from the $\mathrm{Q}$ wave to the $\mathrm{T}$ wave end; $\mathrm{v}$, variance. 


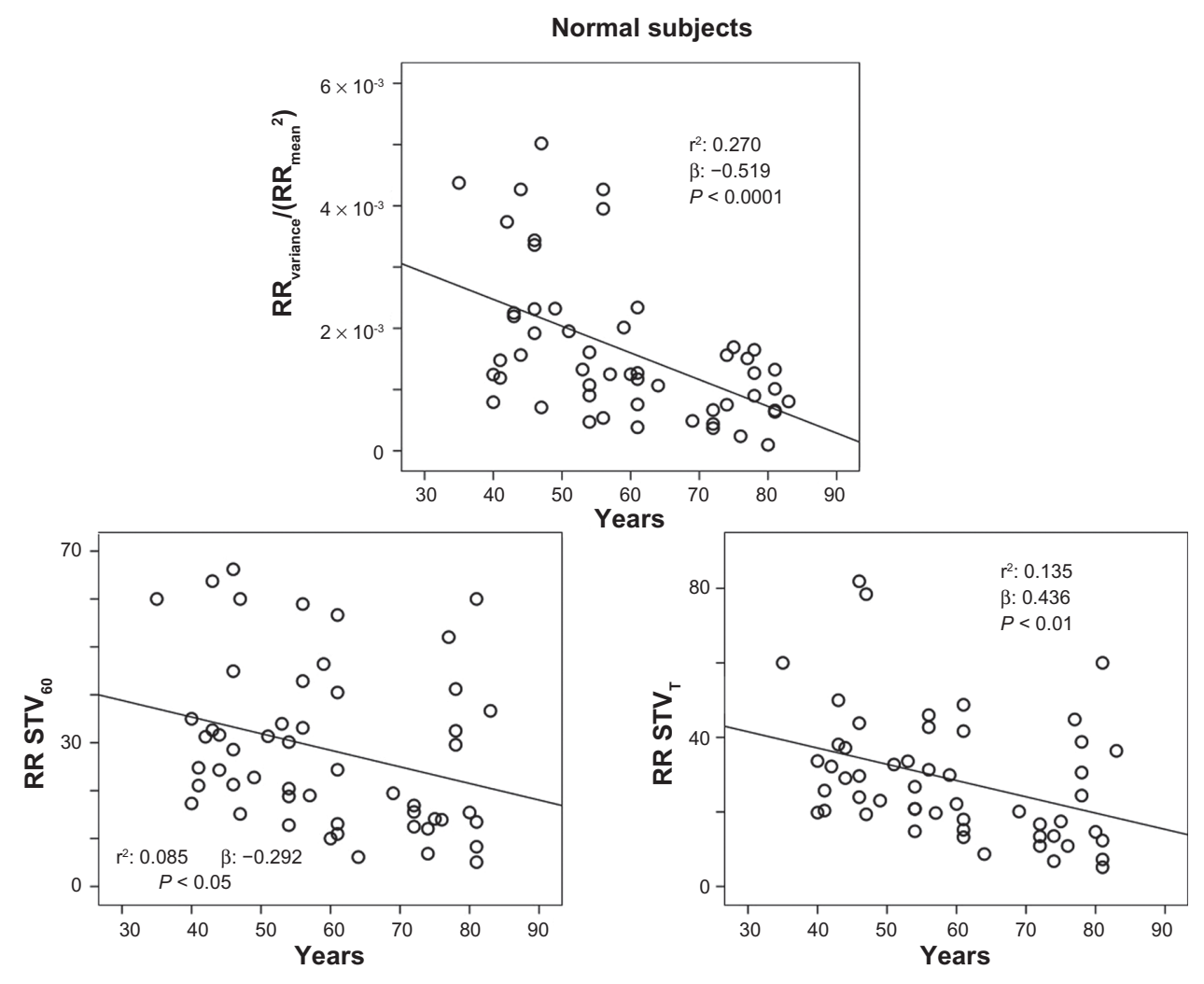

Figure 3 Relationship between age and the resting rate (RR) variability indices (ratio denominator of QTVI, TeVi, and short-term variability [STV], see Methods section), calculated on 5-minute electrocardiogram recordings $\left(R_{\text {variance }} / R_{\text {mean }}{ }^{2}\right.$ and $\left.R R S T V_{T}\right)$ or on 60 consecutive $Q_{R S s}\left(R R S T V_{60}\right)$ in healthy control subjects.

Abbreviations: TeVI, Tend Variability index; Q-T, waves interval.

Some authors believe that $\mathrm{Te}$ is a reliable noninvasive marker of transmural repolarization gradient, whereas others affirm that this period reflects the total spatial ventricular repolarization dispersion. ${ }^{41,46,51}$ Notably, clinical and experimental evidence indicates that Te should be considered as a marker of $I \mathrm{k}_{\mathrm{s}}$ function, especially during sympathetic activation. ${ }^{52,53}$ Indeed, an enhancement in $I \mathrm{~K}_{\mathrm{s}}$ was reported after a $\beta$-adrenergic stimulation, the latter leading to an elevation of intracellular cyclic adenosine monophosphate (cAMP) and an activation of protein kinase A. ${ }^{54}$ Supporting

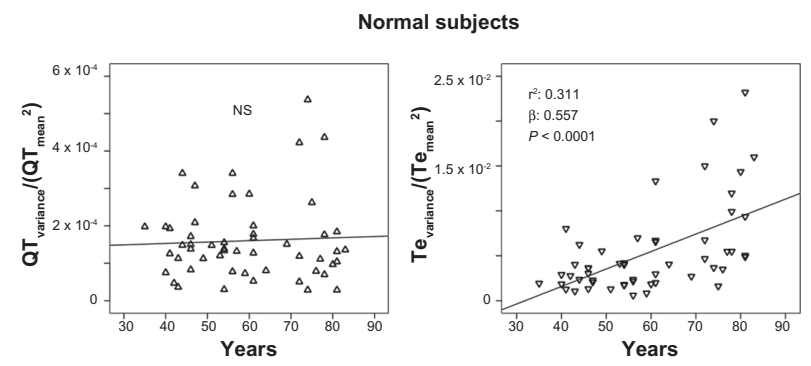

Figure 4 Relationship between age and Te variance/Te mean ${ }^{2}$ (ratio numerator of $\mathrm{T}_{\text {peak }}-\mathrm{T}_{\text {end }}$ variability index, see Methods section).

Notes: No significant relation was reported between age and $\mathrm{QT}_{\text {variance }} / \mathrm{QT}_{\text {mean }}{ }^{2}$ (ratio numerator of TeVl, see Methods section) in healthy control subjects. Abbreviations: TeVI, Tend Variability index; Q-T, waves interval. this datum, it was reported that subjects with concealed type 1 long QT reported a significant increase of Te interval during an infusion of epinephrine, ${ }^{55}$ again favoring a close link between adrenergic burst and $I \mathrm{~K}_{\mathrm{s}}$ activity. Our current data seem to identify a possible role of Te-derived indices only when considering those patients with $\mathrm{CHF}$ aged $<50$ years. However, a real comparison is impossible given the different population enrolled and the lack of a follow-up. A possible explanation, albeit merely speculative, could be that aging per se, due to a downregulation of $\beta$-adrenoreceptor expression and function, could affect Te-derived indices, leading to an age-related loss of their diagnostic utility in patients with CHF. Accordingly, we can hypothesize that, between all indices of myocardial repolarization dispersion, QTVI might remain the only one that could be used to point out an increased SCD risk regardless of patients' age, whereas Te indices should be useful just in middle-aged patients.

\section{Conclusion}

Our data demonstrate a deep influence of age on the short-term variability of repolarization phases, and tend to suggest that only QTVI is able to characterize temporal myocardial repolarization lability in patients with CHF regardless of aging. 


\section{Disclosure}

The authors report no conflicts of interest in this work.

\section{References}

1. Hotta H, Uchida S. Aging of the autonomic nervous system and possible improvements in autonomic activity using somatic afferent stimulation. Geriatr Gerontol Int. 2010;10:S127-S136.

2. Kaye DM, Esler MD. Autonomic control of the aging heart. Neuro Molecular Medicine. 2008;10:179-186.

3. Kishi T. Heart failure as an autonomic nervous system dysfunction. J Cardiol. 2012;59:117-122.

4. Piccirillo G, Ogawa M, Song J, Chong VJ, Joung B, Han S, et al. Power spectral analysis of heart rate variability and autonomic nervous system activity measured directly in healthy dogs and dogs with tachycardiainduced heart failure. Heart Rhythm. 2009;6:546-552.

5. Piccirillo G, Rossi P, Mitra M, et al. Indexes of temporal myocardial repolarization dispersion and sudden cardiac death in heart failure: any difference? Ann Noninv Electrocardiol. 2012; DOI:10.1111/ anec. 12005.

6. Piccirillo G, Magrì D, Pappadà MA, Maruotti A, Ogawa M, Han S, et al. Autonomic nerve activity and the short term variability of $T_{\text {peak }}-T_{\text {end }}$ interval in dogs with pacing-induced heart failure. Heart Rhythm. 2012;9:2044-2050.

7. Piccirillo G, Magrì D, Ogawa $\mathrm{M}$, Song $\mathrm{J}$, Chong VJ, Han $\mathrm{S}$, et al. Autonomic nervous system activity measured directly and QT interval variability in normal and pacing-induced tachycardia heart failure dogs. J Am Coll Cardiol. 2009;54:840-850.

8. Piccirillo G, Cacciafesta M, Lionetti M, Nocco M, Di Giuseppe V, Moisè A, et al. The influence of age, the autonomic nervous system and anxiety on QT interval variability. Clin Sci. 2001;101: 429-438.

9. Piccirillo G, Magnanti M, Matera S, Di Carlo S, De Laurentis T, Torrini A, et al. Age and QT variability index during free breathing, controlled breathing and tilt in patients with chronic heart failure and healthy control subjects. Transl Res. 2006;148:72-78.

10. Janczewski AJ, Lakatta EG. Modulation of sarcoplasmic reticulum $\mathrm{Ca} 2+$ cycling in systolic and diastolic heart failure associated with aging. Heart Fail Rev. 2010;15:431-445.

11. Piccirillo G, Cacciafesta M, Viola E, et al. Influence of aging on cardiac baroreflex sensitivity determined noninvasively by power spectral analysis. Clin Sci. 2001;100:267-274.

12. Piccirillo G, Di Giuseppe V, Nocco M, Lionetti M, Naso C, Tallarico D, et al. Influence of aging and other cardiovascular risk factors on baroreflex sensitivity. J Am Geriatr Soc. 2001;49:1059-1065.

13. Piccirillo G, Fimognari FL, Viola E, Marigliano V. Age-adjusted normal confidence intervals for heart rate variability in healthy subjects during head-up tilt. Int J Cardiol. 1995;50:117-124.

14. Colosimo A, Giuliani A, Mancini AM, Piccirillo G, Marigliano V. Estimating a cardiac age by means of heart rate variability. Am J Physiol. 1997;273:H1841-H1847.

15. Piccirillo G, Bucca C, Bauco C, Cinti AM, Michele D, Fimognari FL, et al. Power spectral analysis of heart rate in subjects over a hundred years old. Int J Cardiol. 1998;63:53-61.

16. Piccirillo G, Magrì D, Naso C, di Carlo $\mathrm{S}$, Moisè $\mathrm{A}$, De Laurentis $\mathrm{T}$, et al. Factors influencing heart rate variability power spectral analysis during controlled breathing in patients with chronic heart failure or hypertension and in healthy normotensive subjects. Clin Sci (Lond). 2004;107:183-190.

17. Tereshchenko LG, Cygankiewicz I, McNitt S, Vazquez R, Bayes-Genis A, Han L, et al. Predictive value of beat-to-beat QT variability index across the continuum of left ventricular dysfunction: competing risks of noncardiac or cardiovascular death and sudden or nonsudden cardiac death. Circ Arrhythm Electrophysiol. 2012;5: $719-727$.
18. Dobson CP, La Rovere MT, Pinna GD, Goldstein R, Olsen C, Bernardinangeli M, et al. QT variability index on 24-hour Holter independently predicts mortality in patients with heart failure: analysis of GISSI-HF trial data. Heart Rhythm. 2011;8:1237-1242.

19. Dobson CP, La Rovere MT, Olsen C, Berardinangeli M, Veniani M, Midi P, et al. 24-hour QT variability in heart failure. J Electrocardiol. 2009;42:500-504.

20. Haigney MC, Zareba W, Nasir JM, McNitt S, McAdams D, Gentlesk PJ, et al; MADIT II investigators. Gender differences and risk of ventricular tachycardia or ventricular fibrillation. Heart Rhythm 2009;6: 180-186.

21. Piccirillo G, Magrì D, Matera S, Magnanti M, Torrini A, Pasquazzi E, et al. QT variability strongly predicts sudden cardiac death in asymptomatic subjects with mild or moderate left ventricular systolic dysfunction: a prospective study. Eur Heart J. 2007;28:1344-1350.

22. Haigney MC, Zareba W, Gentlesk PJ, Goldstein RE, Illovsky M, McNitt S, et al; Multicenter Automatic Defibrillator Implantation Trial II investigators. QT interval variability and spontaneous ventricular tachycardia or fibrillation in the Multicenter Automatic Defibrillator Implantation Trial [MADIT] II. J Am Coll Cardiol. 2004;44:1481-1487.

23. Atiga WL, Calkins H, Lawrence JH, Tomaselli GF, Smith JM, Berger RD. Beat-to-beat repolarization lability identifies patients at risk for sudden cardiac death. J Cardiovasc Electrophysiol. 1998;9:899-908.

24. Piccirillo G, Magrì D, Matera S, Magnanti M, Pasquazzi E, Schifano E, et al. Effects of pink grapefruit juice on QT variability in patients with dilated or hypertensive cardiomyopathy and in healthy subjects. Transl Res. 2008;151:267-272.

25. Piccirillo G, Magrì D, di Carlo S, De Laurentis T, Torrini A, Matera S, et al. Influence of cardiac-resynchronization therapy on heart rate and blood pressure variability: 1-year follow-up. Eur J Heart Fail. 2006;8: 716-722.

26. Huikuri HV, Stein PK. Clinical application of heart rate variability after acute myocardial infarction. Front Physiol. 2012;3:41.

27. Thayer JF, Yamamoto SS, Brosschot JF. The relationship of autonomic imbalance, heart rate variability and cardiovascular disease risk factors. Int J Cardiol. 2010;141:122-131.

28. Cooper LL, Odening KE, Hwang MS, Chaves L, Schofield L, Taylor CA, et al. Electromechanical and structural alterations in the aging rabbit heart and aorta. Am J Physiol Heart Circ Physiol. 2012;302: H1625-H1635.

29. Bapat A, Nguyen TP, Lee JH, Sovari AA, Fishbein MC, Weiss JN, Karagueuzian HS. Enhanced sensitivity of aged fibrotic hearts to angiotensin II- and hypokalemia-induced early after depolarization-mediated ventricular arrhythmias. Am J Physiol Heart Circ Physiol. 2012;302: $\mathrm{H} 2331-\mathrm{H} 2340$.

30. Morita N, Sovari AA, Xie Y, Fishbein MC, Mandel WJ, Garfinkel A, et al. Increased susceptibility of aged hearts to ventricular fibrillation during oxidative stress. Am J Physiol Heart Circ Physiol. 2009;297: H1594-H1605.

31. Aiba T, Tomaselli GF. Electrical remodelling of the failing heart. Curr Opin Cardiol. 2010;25:29-36.

32. Zucker IH, Patel KP, Schultz HD. Neurohumoral stimulation. Heart Fail Clin. 2012;8:87-99.

33. Han S, Kobayashi K, Joung B, Piccirillo G, Maruyama M, Vinters HV, et al. Electroanatomic remodeling of the left stellate ganglion after myocardial infarction. J Am Coll Cardiol. 2012;59:954-961.

34. Ajijola OA, Wisco JJ, Lambert HW, Mahajan A, Stark E, Fishbein MC, Shivkumar K. Extracardiac neural remodeling in humans with cardiomyopathy. Circ Arrhythm Electrophysiol. 2012;5: 1010-1116.

35. Rossi P, Ricci A, De Paulis R, Papi E, Pavaci H, Porcelli D, et al. Epicardial ganglionated plexus stimulation decreases post-operative inflammatory response in humans. Heart Rhythm. 2012;9:943-950.

36. Brack KE, Coote JH, Ng GA. Vagus nerve stimulation protects against ventricular fibrillation independent of muscarinic receptor activation. Cardiovasc Res. 2011;91:437-446. 
37. Hassanabad ZF, Furman BL, Parratt JR, Aughey E. Coronary endothelial dysfunction increases the severity of ischaemia-induced ventricular arrhythmias in rat isolated perfused hearts. Basic Res Cardiol. 1998;93: 241-249.

38. Piccirillo G, Quaglione R, Fimognari F, Moisè A, Mario M, Lionetti M, et al. Influence of $\mathrm{L}$-arginine and vitamin $\mathrm{C}$ on the autonomic nervous system in chronic heart failure secondary to ischemic cardiomyopathy. Am J Cardiol. 2004;93:650-654.

39. Piccirillo G, Nocco M, Moisè A, et al. Influence of vitamin C on baroreflex sensitivity in chronic heart failure. Hypertension. 2003;41: $1240-1245$

40. Panikkath R, Reinier K, Uy-Evanado A, Teodorescu C, Hattenhauer J, Mariani $\mathrm{R}$, et al. Prolonged $\mathrm{T}_{\text {peak }}$-to- $\mathrm{t}_{\text {end }}$ interval on the resting ECG is associated with increased risk of sudden cardiac death. Circ Arrhythm Electrophysiol. 2011;4:441-447.

41. Berger RD, Kasper EK, Baughman KL, Marban E, Calkins H, Tomaselli GF. Beat-to-beat QT interval variability. Novel evidence for repolarization lability in ischemic and nonischemic dilated cardiomyopathy. Circulation. 1997;96:1557-1565.

42. Magrì D, Piccirillo G, Bucci E, Pignatelli G, Cauti FM, Morino S, et al. Increased temporal dispersion of myocardial repolarization in myotonic dystrophy type 1: beyond the cardiac conduction system. Int J Cardiol. 3 2012;156:259-264.

43. Piccirillo G, Magrì D, Mitra M, Rufa A, Zicari E, Stromillo ML, et al. Increased QT variability in cerebral autosomal dominant arteriopathy with subcortical infarcts and leukoencephalopathy. Eur J Neurol. 2008;15:1216-1221

44. Magrì D, Sciomer S, Fedele F, Gualdi G, Casciani E, Pugliese P, et al. Increased QT variability in young asymptomatic patients with betathalassemia major. Eur J Haematol. 2007;79:322-329.

45. Magrì D, Piccirillo G, Quaglione R, Dell'armi A, Mitra M, Velitti S, et al. Effect of acute mental stress on heart rate and QT variability in postmyocardial infarction patients. ISRN Cardiol. 2012;912672.
46. Thomsen MB, Oros A, Schoenmakers M, et al. Proarrhythmic electrical remodelling is associated with increased beat-to-beat variability of repolarization. Cardiovasc Res. 2007;73:521-530.

47. Oosterhoff P, Tereshchenko LG, van der Heyden MA, et al. Short-term variability of repolarization predicts ventricular tachycardia and sudden cardiac death in patients with structural heart disease: a comparison with QT variability index. Heart Rhythm. 2011;8:1584-1590.

48. Janczewski AM, Lakatta EG. Modulation of sarcoplasmic reticulum $\mathrm{Ca}^{2+}$ in systolic and diastolic heart failure. Heart Rev. 2010;15:431-445.

49. Ocorr K, Reeves NL, Wessells RJ, Fink M, Chen HS, Akasaka T, et al. KCNQ potassium channel mutations cause cardiac arrhythmias in Drosophila that mimic the effects of aging. PNAS. 2007;104:3943-3948.

50. Aiba T, Tomaselli GF. Electrical remodeling in the failing heart. Curr Opin Cardiol. 2010;25:26-36.

51. Patel C, Burke JF, Patel H, et al. Is there a significant transmural gradient in repolarization time in the intact heart? Cellular basis of the $\mathrm{T}$ wave: a century of controversy. Circ Arrhythm Electrophysiol. 2009;2:80-88.

52. Xia Y, Liang Y, Kongstad O, et al. In vivo validation of the coincidence of the peak and end of the $\mathrm{T}$ wave with full repolarization of the epicardium and endocardium in swine. Heart Rhythm. 2005;2: $162-169$.

53. Izumi D, Chinushi M, Iijima $\mathrm{K}$, et al. The peak-to-end of the $\mathrm{T}$ wave in the limb ECG leads reflects total spatial rather than transmural dispersion of ventricular repolarization in an anthopleurin-A model of prolonged QT interval. Heart Rhythm. 2012;9:796-803.

54. Cheng JH, Kodama I. Two components of delayed rectifier K+ current in heart: molecular basis, functional diversity, and contribution to repolarization. Acta Pharmacol Sin. 2004;25:137-145.

55. Shimizu W, Noda T, Takaki H, Kurita T, Nagaya N, Satomi K, et al. Epinephrine unmasks latent mutation carriers with LQT1 form of congenital long-QT syndrome. J Am Coll Cardiol. 2003;41:633-642.
Clinical Interventions in Aging

\section{Publish your work in this journal}

Clinical Interventions in Aging is an international, peer-reviewed journal focusing on evidence-based reports on the value or lack thereof of treatments intended to prevent or delay the onset of maladaptive correlates of aging in human beings. This journal is indexed on PubMed Central, MedLine, the American Chemical Society's 'Chemical Abstracts

\section{Dovepress}

Service' (CAS), Scopus and the Elsevier Bibliographic databases. The manuscript management system is completely online and includes a very quick and fair peer-review system, which is all easy to use. Visit http://www.dovepress.com/testimonials.php to read real quotes from published authors. 